\title{
Iron-in-perovskite oxygen barometry and diamond resorption in kimberlites and lamproites from southern Africa, Russia and Australia
}

\author{
T. Nowicki ${ }^{1}$, M. Galloway ${ }^{1}$, A. le Roex ${ }^{2}$, J. Gurney ${ }^{1}$, C. Smith ${ }^{1}$, and D. Canil ${ }^{3}$ \\ (1) Mineral Services Group, Ndabeni, Cape Town, South Africa; (2) University of Cape Town, Rondebosch, Cape \\ Town, South Africa; (3) University of Victoria, British Columbia, Canada
}

\begin{abstract}
Introduction
Resorption of diamond populations in kimberlites and lamproites is well documented and has a significant impact on diamond content, size-distribution and value. Discrepancies in the extent of resorption displayed by diamonds enclosed in mantle xenoliths relative to those extracted directly from the host kimberlite suggests that a significant amount resorption takes place in the magma itself. The extent of resorption observed in diamond populations from kimberlites and lamproites is highly variable and evidence suggests that the oxidation state of the host magma may be a key controlling factor (Fedortchouk et al., 2007).
\end{abstract}

Until recently, assessments of the potential for diamond resorption by kimberlites primarily relied on the composition of megacryst ilmenite. It has been shown that in many cases the average ferric iron content of ilmenite megacryst populations can be related to the extent of diamond resorption and, conversely, to late stage diamond growth in kimberlite (Horwood, 1998). However, given that ilmenite megacrysts are xenocryst phases that are not directly related to the host magma in which much of the diamond resorption takes place, the basis for this relationship is not clear. Furthermore, there are examples of kimberlites for which the relationship does not appear to hold, with unresorbed diamond occurring in kimberlites with relatively oxidized ilmenite and visa versa. In many cases, ilmenite megacrysts are absent or not present in sufficient quantities to provide reliable estimates of the potential for diamond resorption.

A recently developed oxygen barometer based on the ferric iron content of $\mathrm{CaTiO}_{3}$ perovskite (Bellis and Canil, 2007) provides a more direct estimate of the oxygen fugacity of kimberlite magmas. Recent application of this technique to three kimberlite localities in the Lac de Gras area in Canada indicates a correlation between perovskite-based $\mathrm{fO}_{2}$ estimates, diamond resorption and possibly even depth of origin of the magma. Perovskite is common as a trace groundmass mineral in most kimberlites and olivine lamproites and is resistant to alteration processes that typically obscure the primary mineralogy of these rocks. Thus it potentially provides a powerful tool for estimating the oxygen fugacity of kimberlite and lamproite magmas and thereby obtaining a direct indication of the potential for resorption of diamonds.

In this contribution, we present the results of detailed chemical analysis of perovskite in kimberlite and lamproite samples from several localities in southern Africa, Russia and Australia. Oxygen fugacity is estimated using the perovskite oxygen barometer and is compared to estimates of resorption based on diamond population studies. The results of this work are used to evaluate the general applicability of the perovskite oxygen barometer to kimberlites and lamproites worldwide and to further constrain relationships between the oxygen fugacity of the magma and the degree of diamond resorption.

\section{Samples and methods}

Perovskite was analysed in thirty samples from seventeen localities in South Africa, Lesotho, Botswana, Russia and Australia (Table 1). These are mostly kimberlites but also include an olivine lamproite. The localities were selected primarily on the basis of availability of information relating to diamond resorption, availability of sample material (the majority were derived from the collection of the Kimberlite Research Group, Department of Geological Sciences, University of Cape Town) and the presence of fresh perovskite suitable for analysis.

Perovskite was analysed by electron microprobe at the Department of Geological Sciences, University of Cape Town. The following oxides were determined: $\mathrm{SiO}_{2}$, $\mathrm{TiO}_{2}$, total iron as $\mathrm{Fe}_{2} \mathrm{O}_{3}, \mathrm{MnO}, \mathrm{MgO}, \mathrm{CaO}, \mathrm{Na} 2 \mathrm{O}$, $\mathrm{SrO}, \mathrm{La}_{2} \mathrm{O}_{3}, \mathrm{Ce}_{2} \mathrm{O}_{3}, \mathrm{Nb}_{2} \mathrm{O}_{5}, \mathrm{ThO}_{2}, \mathrm{Pr}_{2} \mathrm{O}_{3}$, and $\mathrm{Ta}_{2} \mathrm{O}_{5}$. Counting times were 10 seconds on peak and 5 seconds on background, except for $\mathrm{Nb}, \mathrm{Sr}, \mathrm{La}, \mathrm{Ce}$ and $\mathrm{Nd}$ (20/10) and Fe (40/20). To verify analytical accuracy, we analysed a selection of perovskites previously analysed by Canil and Bellis (2007). Our results were within error of the original analyses.

Oxygen fugacity was determined for each perovskite analysis using the iron-in-perovskite oxygen barometer calibrated by Bellis and Canil (2007) which relates $\mathrm{fO}_{2}$ (relative to the NNO buffer) to the $\mathrm{Fe}$ and $\mathrm{Nb}$ content of perovskite as follows:

$\Delta \mathrm{NNO}=[(-0.5 \mathrm{x} \mathrm{Nb})+(\mathrm{Fe}-0.03)] / 0.004$. 
Table 1: Summary of information for each locality investigated in this study. PI = diamond preservation index (see text for explanation). Localities are ranked based on estimated degree of preservation (Preserv. Rank).

\begin{tabular}{llcccccccc}
\hline Country & Province & $\begin{array}{c}\text { No. of } \\
\text { samples }\end{array}$ & $\begin{array}{c}\text { No. of } \\
\text { grains }\end{array}$ & $\begin{array}{c}\text { Mean } \\
\Delta \text { NNO }\end{array}$ & $\begin{array}{c}\text { Min } \\
\Delta \text { NNO }\end{array}$ & $\begin{array}{c}\text { Max } \\
\Delta \text { NNO }\end{array}$ & PI & $\begin{array}{c}\text { Preserv. } \\
\text { Rating }\end{array}$ & $\begin{array}{c}\text { Preserv. } \\
\text { Rank }\end{array}$ \\
\hline Russia & Yakutia & 1 & 9 & -2.9 & -3.3 & -2.5 & 0.73 & 1 & 1 \\
Russia & Yakutia & 1 & 8 & -3.3 & -3.7 & -2.9 & 0.60 & 1 & 2 \\
Russia & Yakutia & 2 & 4 & -3.1 & -3.8 & -2.0 & 0.60 & 1 & 3 \\
Russia & Yakutia & 2 & 8 & -3.0 & -3.6 & -2.2 & 0.50 & 1 & 4 \\
South Africa & Kalahari & 2 & 8 & -2.3 & -3.3 & -1.3 & 0.50 & 2 & 5 \\
South Africa & Kalahari & 2 & 8 & -2.4 & -2.9 & -1.6 & 0.36 & 2 & 6 \\
South Africa & Kalahari & 1 & 9 & -3.9 & -4.1 & -3.6 & 0.38 & 2 & 7 \\
South Africa & Kalahari & 2 & 9 & -4.0 & -4.3 & -3.6 & 0.37 & 2 & 8 \\
South Africa & Kalahari & 2 & 9 & -3.1 & -3.6 & -2.4 & 0.30 & 3 & 9 \\
South Africa & Kalahari & 2 & 5 & -2.1 & -2.4 & -1.5 & 0.22 & 2 & 10 \\
Botswana & Kalahari & 2 & 9 & -3.7 & -4.1 & -3.1 & 0.11 & 3 & 11 \\
Lesotho & Kalahari & 2 & 7 & -2.2 & -3.0 & -1.3 & 0.20 & 3 & 12 \\
South Africa & Kalahari & 1 & 8 & -3.4 & -4.2 & -2.7 & 0.11 & 3 & 13 \\
South Africa & Kalahari & 2 & 6 & -3.5 & -4.1 & -3.2 & 0.10 & 3 & 14 \\
South Africa & Kalahari & 2 & 8 & -3.4 & -4.2 & -2.7 & 0.10 & 3 & 15 \\
Lesotho & Kalahari & 2 & 9 & -1.8 & -3.3 & -0.2 & 0.01 & 4 & 16 \\
Australia & Kimberley & 2 & 10 & -1.2 & -2.3 & -0.5 & 0.00 & 4 & 17 \\
\hline
\end{tabular}

Information on the degree of preservation of diamonds at each of the studied localities was obtained from a variety of sources. The amount of information and reliability of observations is highly variable and hence estimates of diamond preservation / resorption are somewhat subjective. Nonetheless, all efforts were made to ensure that the estimates are not biased and are a reasonable representation of the average diamond population present at each locality. The ratio of octahedral to total octahedral plus dodecahedral diamonds present in each population (the diamond "preservation index", or PI) forms the basis of diamond preservation estimates (Table 1) but these have been augmented by other descriptive information where available. Based on PI and other diamond morphology observations, each locality was assigned to one of four classes of diamond preservation: 1 - well preserved with $\mathrm{PI}>0.50 ; 2$ - moderately well-preserved, generally with PI values between 0.5 and 0.3 ; 3 poorly preserved generally with PI values between 0.3 and 0.1 ; and $4-$ marginally preserved $(\mathrm{PI}<10)$. No attempt has been made to resolve potential variations in degree of diamond resorption between different phases within individual bodies.

The average compositions of perovskite analysed from each locality are provided in Table 2 and a summary of $\triangle$ NNO results and diamond preservation estimates is provided in Table 1 . The mean and range of $\Delta \mathrm{NNO}$ values and oxide concentrations given in Tables 1 and 2 exclude outlier values (defined as those deviating from the original mean by more than 2 times the standard deviation). Seven of a total of 134 analyses were excluded in this way. Mean, minimum and maximum $\triangle \mathrm{NNO}$ values are illustrated in Figure 1, sorted according to estimated degree of diamond preservation.

\section{Results and discussion}

The average $\Delta \mathrm{NNO}$ values for kimberlites analysed in this study range from -4.0 to -1.2 with most localities yielding values between -3 and -2 (Fig. 1). Variation in $\triangle \mathrm{NNO}$ within the individual localities studied is in most cases within the uncertainty of the method and does not provide any evidence for multiple populations of perovskite. Three localities (Letseng, Ellendale and Wesselton) show wider ranges in $\triangle N N O$ but in each case, the data for individual grains do not define clear sub-populations indicative of multiple perovskite generations. The range of $\mathrm{fO}_{2}$ values observed in the bodies examined in this study is within the margin of uncertainty ( $\pm 1 \mathrm{fO}_{2} \log$ unit) of the oxygen barometer calibration and corresponds with the mode for kimberlitic perovskite worldwide, as determined by Canil and Bellis (2007) based on perovskite compositions reported in the literature. None of the kimberlites yield indications of the more oxidising conditions of crystallisation ( $\Delta$ NNO values up to +6 ) reported by Canil and Bellis (2007) for certain kimberlites from Canada.

The two localities with the highest average $\mathrm{fO}_{2}$ values determined in this study (Ellendale and Letseng) have the lowest estimated degree of diamond preservation. This suggests that in these bodies, the observed extreme resorption of diamonds is at least partly related to relatively oxidising host magmas. However, $\triangle \mathrm{NNO}$ values for other kimberlites do not show any systematic relationship to the degree of preservation of diamonds. 
Table 2: Average perovskite compositions (values in wt \%) for localities investigated in this study.

\begin{tabular}{|c|c|c|c|c|c|c|c|c|c|c|c|c|c|c|c|c|c|c|c|}
\hline Locality & $\mathrm{n}$ & $\Delta \mathrm{NNO}$ & $\mathrm{SiO}_{2}$ & $\mathrm{TiO}_{2}$ & $\mathrm{Al}_{2} \mathrm{O}_{3}$ & $\mathrm{Fe}_{2} \mathrm{O}_{3}$ & $\mathrm{MnO}$ & $\mathrm{MgO}$ & $\mathrm{CaO}$ & $\mathrm{Na}_{2} \mathrm{O}$ & SrO & $\mathrm{La}_{2} \mathrm{O}_{3}$ & $\mathrm{Ce}_{2} \mathrm{O}_{3}$ & $\mathrm{Nb}_{2} \mathrm{O}_{5}$ & $\mathrm{Nd}_{2} \mathrm{O}_{3}$ & $\mathrm{ThO}_{2}$ & $\mathrm{Pr}_{2} \mathrm{O}_{3}$ & $\mathrm{Ta}_{2} \mathrm{O}_{5}$ & Total \\
\hline Premier & 9 & -3.98 & 0.04 & 56.14 & 0.22 & 0.92 & 0.04 & 0.04 & 39.93 & 0.39 & 0.00 & 0.29 & 0.93 & 0.36 & 0.36 & 0.23 & 0.05 & 0.07 & 100.03 \\
\hline Frank Smith & 9 & -3.90 & 0.02 & 54.77 & 0.10 & 0.97 & 0.00 & 0.05 & 37.36 & 0.68 & 0.00 & 0.96 & 2.87 & 0.51 & 1.02 & 0.46 & 0.33 & 0.09 & 100.20 \\
\hline Orapa & 9 & -3.65 & 0.01 & 55.00 & 0.03 & 1.06 & 0.03 & 0.06 & 39.13 & 0.52 & 0.15 & 0.57 & 1.51 & 0.61 & 0.53 & 0.00 & 0.00 & 0.00 & 99.22 \\
\hline DeBeers & 6 & -3.53 & 0.04 & 54.55 & 0.24 & 1.11 & 0.01 & 0.03 & 37.37 & 0.66 & 0.00 & 0.73 & 2.65 & 0.68 & 1.17 & 0.64 & 0.31 & 0.12 & 100.31 \\
\hline Kamfersdam & 8 & -3.39 & 0.08 & 52.66 & 0.22 & 1.18 & 0.01 & 0.12 & 37.37 & 0.73 & 0.00 & 0.80 & 2.73 & 0.88 & 1.15 & 0.48 & 0.33 & 0.10 & 98.85 \\
\hline DuToits Pan & 7 & -3.38 & 0.01 & 54.63 & 0.07 & 1.12 & 0.01 & 0.05 & 37.75 & 0.63 & 0.00 & 0.73 & 2.50 & 0.61 & 1.10 & 0.49 & 0.29 & 0.09 & 100.07 \\
\hline Aikhal & 8 & -3.29 & 0.02 & 54.59 & 0.20 & 1.15 & 0.02 & 0.06 & 39.12 & 0.39 & 0.00 & 0.71 & 1.92 & 0.63 & 0.61 & 0.29 & 0.18 & 0.10 & 99.99 \\
\hline Jubilee & 4 & -3.09 & 0.33 & 53.55 & 0.14 & 1.28 & 0.02 & 0.18 & 36.58 & 0.72 & 0.00 & 0.91 & 2.70 & 0.96 & 0.90 & 0.63 & 0.30 & 0.19 & 99.38 \\
\hline Samada & 8 & -3.06 & 0.01 & 55.46 & 0.08 & 1.17 & 0.03 & 0.05 & 38.96 & 0.61 & 0.16 & 0.57 & 1.81 & 0.51 & 0.70 & 0.00 & 0.00 & 0.00 & 100.12 \\
\hline Udachnaya & 7 & -3.01 & 0.01 & 53.57 & 0.15 & 1.33 & 0.00 & 0.15 & 36.84 & 0.74 & 0.00 & 1.11 & 3.22 & 1.04 & 1.08 & 0.70 & 0.40 & 0.22 & 100.56 \\
\hline Zarnitsa & 9 & -2.88 & 0.02 & 55.40 & 0.23 & 1.25 & 0.04 & 0.08 & 39.31 & 0.41 & 0.00 & 0.58 & 1.60 & 0.60 & 0.54 & 0.15 & 0.13 & 0.07 & 100.42 \\
\hline Monastery & 8 & -2.36 & 0.02 & 54.76 & 0.19 & 1.39 & 0.03 & 0.03 & 37.96 & 0.66 & 0.00 & 0.68 & 2.07 & 0.73 & 0.81 & 0.28 & 0.22 & 0.08 & 99.91 \\
\hline Wesselton & 7 & -2.31 & 0.01 & 53.51 & 0.11 & 1.41 & 0.00 & 0.05 & 36.18 & 0.94 & 0.00 & 1.03 & 3.45 & 0.84 & 1.43 & 0.76 & 0.44 & 0.14 & 100.29 \\
\hline Kao & 7 & -2.23 & 0.03 & 55.23 & 0.24 & 1.33 & 0.02 & 0.09 & 39.65 & 0.38 & 0.04 & 0.50 & 1.43 & 0.38 & 0.57 & 0.13 & 0.07 & 0.04 & 100.15 \\
\hline Bultfontein & 7 & -2.08 & 0.04 & 52.18 & 0.20 & 1.47 & 0.00 & 0.08 & 35.74 & 0.90 & 0.03 & 1.24 & 4.16 & 0.90 & 1.71 & 0.69 & 0.48 & 0.13 & 99.96 \\
\hline Letseng & 9 & -1.80 & 0.02 & 55.58 & 0.24 & 1.40 & 0.03 & 0.04 & 40.05 & 0.33 & 0.00 & 0.40 & 1.20 & 0.28 & 0.45 & 0.14 & 0.07 & 0.04 & 100.27 \\
\hline Ellendale & 9 & -1.19 & 0.62 & 52.04 & 0.27 & 1.60 & 0.00 & 0.12 & 34.92 & 0.80 & 0.00 & 1.69 & 4.14 & 0.68 & 1.11 & 0.50 & 0.55 & 0.10 & 99.15 \\
\hline
\end{tabular}

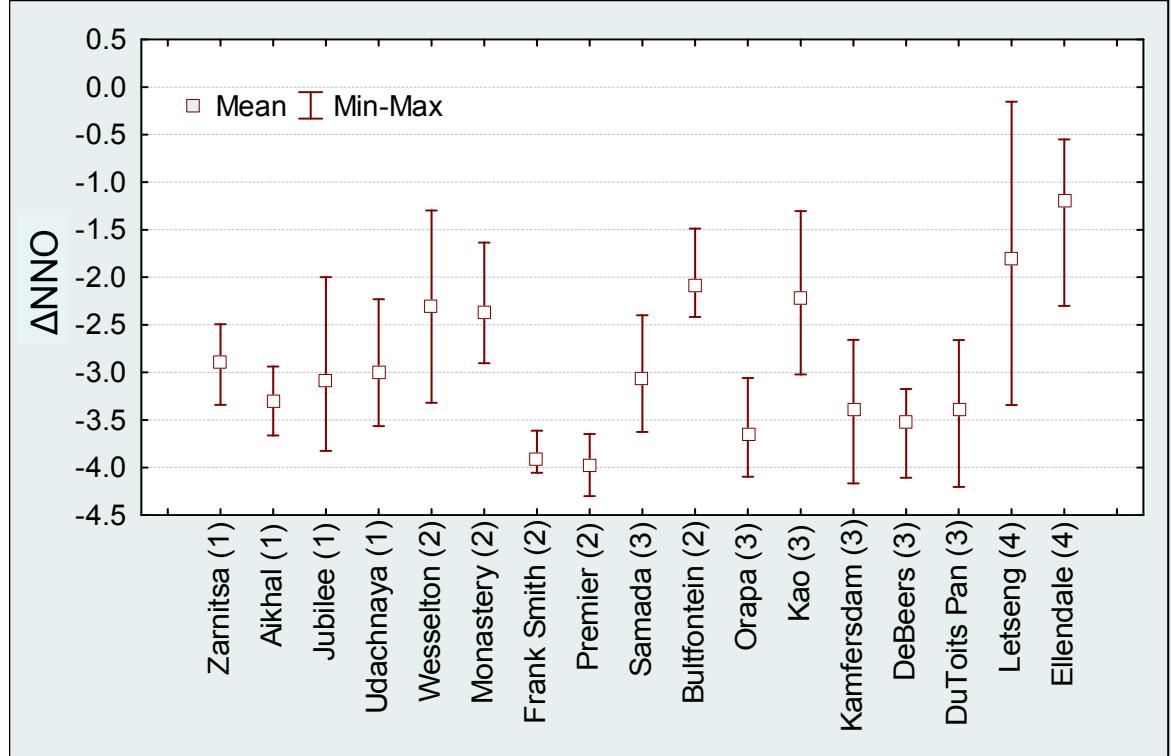

Figure 1: Plot illustrating the mean and range of $\triangle \mathrm{NNO}$ values for each locality studied. Localities are ordered based on estimated degree of diamond preservation.

The four Russian kimberlites which contain diamonds with the highest degree of preservation all have very similar $\triangle \mathrm{NNO}$ values close to the average for the dataset $(\sim-3.0)$. Furthermore, perovskite from the DeBeers and DuToits Pan kimberlites, both known to have a high proportion of resorbed diamond forms, yield $\triangle$ NNO values that are within error of the Russian kimberlites but that, if anything, indicate slightly more reducing conditions of crystallisation (Fig. 1).

\section{Conclusions}

Application of the iron-in-perovskite oxygen barometer of Bellis and Canil (2007) to sixteen kimberlites from Southern Africa and Russia, and one lamproite from Australia, yield $\mathrm{fO}_{2}$ values similar to those estimated for other kimberlites worldwide and do not show evidence for highly oxidising conditions. Other than for the two bodies with the most extensively resorbed diamond populations, calculated $\mathrm{fO}_{2}$ values do not correlate with degree of diamond preservation. This suggests that, in the case of the majority of localities reported here, the oxidation state of the magma is not the main factor causing diamond resorption. These results may indicate that a significant amount of resorption takes place prior to entrainment of the diamond in its host magma.

\section{References}

Bellis, A. and Canil, D., 2007. Ferric iron in $\mathrm{CaTiO}_{3}$ perovskite as an oxygen barometer for kimberlitic magmas I: experimental calibration. Journal of Petrology, 18, 219-230.

Canil, D. and Bellis, A., 2007. Ferric iron in $\mathrm{CaTiO}_{3}$ perovskite as an oxygen barometer for kimberlitic magmas II: applications. Journal of Petrology, 18, 231-252.

Fedortchouk, Y., Canil, D. and Semenets, E., 2007. Mechanisms of diamond oxidation and their bearing on the fluid composition in kimberlite magmas. American Mineralogist, 92, 1200-1212.

Horwood, S.J., 1998. The use of upper mantle derived ilmenite to predict preservation of diamond parcels in kimberlite. Unpublished MSc. Thesis, University of Cape Town, $154 \mathrm{p}$. 